\title{
Medical education in Saudi Arabia: a review of recent developments and future challenges
}

A. Telmesani, ${ }^{1}$ R.G. Zaini ${ }^{7}$ and H.O. Ghazi ${ }^{1}$

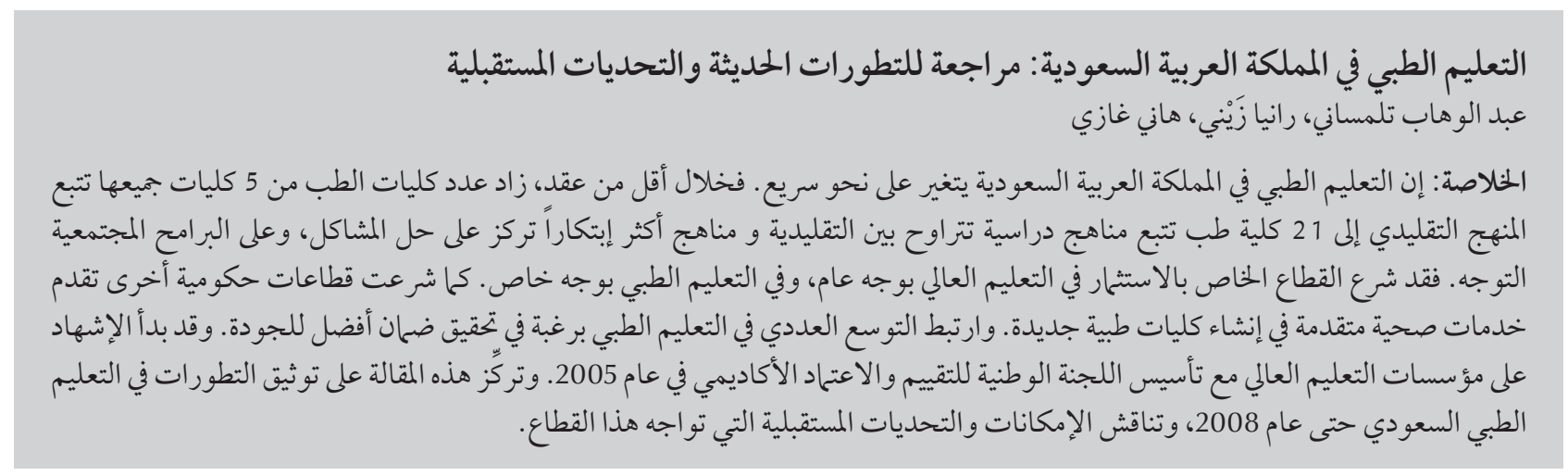

ABSTRACT Medical education has been changing rapidly in Saudi Arabia. Within a decade, the number of medical colleges increased from 5 medical schools with traditional disciplined-based curricula to 21 medical colleges with varied curricula ranging from the traditional to more innovative, problem-based, communityoriented programmes. The private sector has started investing in higher education generally and medical education in particular. Also other government sectors that provide advanced health services have started established new medical colleges. The expansion of quantity in medical education has been associated with a drive for greater quality assurance. Accreditation of higher education institutes began with the establishment of the National Commission for Academic Assessment and Accreditation in 2005. This review focuses on documenting developments in Saudi medical education up to 2008 and discussing the future potential and challenges facing the sector.

\section{Enseignement médical en Arabie saoudite : revue des récentes évolutions et des défis à venir}

RÉSUMÉ L'enseignement médical a évolué rapidement en Arabie saoudite. En l'espace d'une décennie, le nombre de facultés de médecine est passé de cinq établissements proposant un programme traditionnel reposant sur I'enseignement de disciplines, à vingt et un établissements offrant divers programmes, des plus traditionnels aux plus innovants, à base de résolution de problèmes et orientés vers la population. Le secteur privé a commencé à investir dans l'enseignement supérieur en général et dans l'enseignement médical en particulier. En outre, d'autres secteurs publics prestataires de services de santé de niveau avancé ont créé de nouvelles facultés de médecine. La prolifération de l'offre de cursus médicaux a été associée à une campagne pour une meilleure assurance qualité. L'agrément des instituts d'enseignement supérieur a débuté avec la création de la National Commission for Academic Assessment and Accreditation [Commission nationale d'évaluation académique et d'agrément] en 2005. Cette revue est axée sur les informations disponibles concernant l'évolution de l'enseignement médical saoudien jusqu'en 2008, et évoque le potentiel de ce secteur et les défis auxquels il sera confronté. 


\section{First phase of medical education in Saudi Arabia}

Saudi Arabia occupies the major part of the Arabian peninsula and has a population of approximately 23 million [1]. After the foundation of the country in 1932, health services began to advance from a reliance on traditional medicine towards a modern health care system with health care personnel drawn mainly from neighbouring Arab countries and the Indian subcontinent. Later, in a government-sponsored development plan, hundreds of Saudi Arabians with high-school diplomas were given scholarships abroad to study medicine and allied health sciences. This scheme continued until 1967 when King Saud University established the first medical college in the capital city Riyadh in affiliation with the London College of Medicine. In 1975 a further 2 medical colleges were established at King Abdul-Aziz University and King Faisal University, and in 1980 King Saud University opened a branch college in Abha, the southern region, which later became King Khalid University. In 1996, Umm Al-Qura University established the newest medical college for the first phase of Saudi medical education. However, the output of these 5 colleges was not sufficient to bridge the gap in supply and demand for Saudi physicians. In 2006, Saudi Arabian nationals constituted less than $20 \%$ of the physicians working in the country [1].

The first phase of medical education in Saudi Arabia lasted for over 3 decades. Within this era, the 5 former medical colleges followed the same 6-year traditional curriculum, which consisted of 3 years of basic and medical science courses, 3 years of clinical training, followed by a 1-year internship. There were minor differences between colleges in the arrangement of the subjects and disciplines. Teacher-centred learning strategies were the dominant form of instruction.

In the early 2000s concerns about the disadvantages of the traditional curriculum design began to be raised and calls for change increased among the Saudi medical community. The classic teacher-centred approach with copious lectures has limited opportunities for more effective student-centred learning opportunities. One of the limitations is overcrowding of the curriculum, with overemphasis on certain subjects and the inclusion of some less relevant subjects [2-6]. In the United Kingdom these problems have been shown to have a negative impact on students' academic achievement and the educational environment $[7,8]$. The poor teaching environment was also highlighted in studies from medical schools in Saudi Arabia and Yemen which follow a traditional didactic system [9].

A vigorous debate began among Saudi scholars about the divergence between what is expected of medical graduates as new doctors and the content of Saudi medical programmes $[4,5,10]$. This debate raised concerns among academics and medical school deans, which has stimulated a drive to reform the curriculum in most colleges towards a more student-centred and self-learning approach [11]. The importance of evidence-based medical education [12] as a tool in medical programmes has also been discussed in the region [13].

\section{Second phase of medical education in Saudi Arabia}

Saudi medical education has entered a new phase. The Ministry of Higher Education (MOHE) has taken steps to develop higher education in general and medical education in particular. Many new universities have been established and new medical colleges have been announced. The private sector has been invited to contribute and invest in higher education. By 2008, there were 10 new medical colleges that were affiliated with the MOHE and 3 private medical colleges were licensed. In addition, the Ministry of Health $(\mathrm{MOH})$ and the National Guard established their own medical colleges_-King Fahad Medical City and King Saud bin Abdulaziz University for Health Sciences respectively_-raising to 21 the number of medical colleges in Saudi Arabia. In 2005, a national accreditation agency for higher education was established; the National Commission for Academic Assessment and Accreditation (NCAAA).

This second phase of medical education is witnessing a nationwide movement toward innovation in medical education programmes, with a drive to excellence and recognition by international agencies and institutions. Most of the newly established medical colleges follow more innovative medical programmes and have established international partnerships with elite educational institutes (Table 1). The educational strategies adopted include a more integrated curriculum, a focus on problem-based learning and the development of community-oriented and community-based learning. For example, King Saud bin Abdulaziz University for Health Sciences (KSAU-HS) includes both graduate and undergraduate entry to a problem-based learning programme, while Qassim University (QU) follow a problem-based learning, community-oriented programme. Older medical colleges have mostly undergone systematic reforms towards a hybrid,integrated,community-oriented, community-based or problem-oriented curriculum, such as at the medical colleges atJazan University, King Abdulaziz University and King Saud University. Other colleges continue to follow the same classic, discipline-based, teachercentred curriculum. 


\begin{tabular}{|c|c|c|c|c|}
\hline Name & Location & Launched & Sector & Type of curriculum \\
\hline King Saud University & Riyadh & 1967 & Government & $\begin{array}{l}\text { Reformed in } 2009 \text { to integrated } \\
\text { curriculum }\end{array}$ \\
\hline King Abdulaziz University & Jeddah & 1975 & Government & $\begin{array}{l}\text { Reformed in } 2006 \text { to integrated, } \\
\text { problem-based learning curriculum }\end{array}$ \\
\hline King Faisal University & Dammam & 1975 & Government & $\begin{array}{l}\text { Classic discipline-based, teacher- } \\
\text { centred programme }\end{array}$ \\
\hline King Khalid University & Abha & 1982 & Government & $\begin{array}{l}\text { Classic discipline-based, teacher- } \\
\text { centred programme }\end{array}$ \\
\hline Umm Al Qura University & Makkah & 1996 & Government & $\begin{array}{l}\text { Classic discipline-based, teacher- } \\
\text { centred programme }\end{array}$ \\
\hline Al Qassim University & Qassim & 2001 & Government & $\begin{array}{l}\text { Problem-based learning, } \\
\text { community-oriented curriculum }\end{array}$ \\
\hline Taibah University & Madinah & 2001 & Government & $\begin{array}{l}\text { Classic discipline-based, teacher- } \\
\text { centred programme }\end{array}$ \\
\hline King Faisal University & Al Hassa & 2001 & Government & $\begin{array}{l}\text { Classic discipline-based, teacher- } \\
\text { centred programme }\end{array}$ \\
\hline Jazan University & Jazan & 2001 & Government & $\begin{array}{l}\text { Reformed in } 2005 \text { to integrated, } \\
\text { community-oriented, problem- } \\
\text { based learning curriculum }\end{array}$ \\
\hline King Fahd Medical City & Riyadh & 2004 & Government & $\begin{array}{l}\text { Integrated, problem-based learning } \\
\text { curriculum }\end{array}$ \\
\hline $\begin{array}{l}\text { King Saud bin Abdulaziz University } \\
\text { for Health Sciences }\end{array}$ & Riyadh & 2004 & Government & $\begin{array}{l}\text { Integrated, problem-based learning } \\
\text { curriculum }\end{array}$ \\
\hline Ibn Seena Medical Colleges & Jeddah & 2004 & Private & Hybrid, integrated curriculum \\
\hline Taif University & Taif & 2005 & Government & Hybrid, integrated curriculum \\
\hline $\begin{array}{l}\text { Batterjee College for Medical } \\
\text { Sciences and Technology }\end{array}$ & Jeddah & 2006 & Private & $\begin{array}{l}\text { Integrated, problem-based learning } \\
\text { curriculum }\end{array}$ \\
\hline Najran University & Najran & 2007 & Government & $\begin{array}{l}\text { Classic discipline-based, teacher- } \\
\text { centred programme }\end{array}$ \\
\hline Tabuk University & Tabuk & 2007 & Government & $\begin{array}{l}\text { Classic discipline-based, teacher- } \\
\text { centred programme }\end{array}$ \\
\hline Al Jouf University & Al Jouf & 2008 & Government & $\begin{array}{l}\text { Classic discipline-based, teacher- } \\
\text { centred programme }\end{array}$ \\
\hline Alfaisal University & Riyadh & 2008 & Private & $\begin{array}{l}\text { Problem-based learning and } \\
\text { community-based curriculum }\end{array}$ \\
\hline $\begin{array}{l}\text { Al-Imam Mohammed bin Saud } \\
\text { Islamic University }\end{array}$ & Riyadh & 2008 & Government & $\begin{array}{l}\text { Integrated, problem-based learning, } \\
\text { community-oriented curriculum }\end{array}$ \\
\hline Hail University & Hail & 2008 & Government & $\begin{array}{l}\text { Integrated, problem-based learning } \\
\text { curriculum }\end{array}$ \\
\hline $\begin{array}{l}\text { King Saud bin Abdulaziz University } \\
\text { for Health Sciences }\end{array}$ & Jeddah & 2008 & Government & $\begin{array}{l}\text { Integrated, problem-based learning } \\
\text { curriculum }\end{array}$ \\
\hline
\end{tabular}

In parallel with the recent expansion of the quantity of Saudi medical education, calls for establishing quality indicators are increasing. The experiences of the first innovative medical colleges at Qassim University and KSAU-HS need to be evaluated and studied. Some of the achievement of the KSAU-HS medical colleges is their recognition of the World Federation for Medical Education in addition to the national accreditation by the NCAAA.

Another issue in medical education in Saudi Arabia, as in many countries of the Eastern Mediterranean region, is the language of instruction. Teaching in medical colleges is conducted in English language. The disadvantages of teaching medicine in a foreign language and the added stress this can impose on students is poorly addressed in the literature. Foreign language instruction can pose a major difficulty for new medical students who have suboptimal competence in the English language. It has been shown that non-native English speakers studying medicine in English 
have problems with medical vocabulary and practical problems due to different procedural and cultural expectations [14]. Learning medicine through their native Arabic language has been advocated by some senior academicians [15]. The advantages and disadvantages of learning and teaching medicine in a non-native language and its effect on the learning process has not been thoroughly addressed to date in Saudi Arabia

\section{Admissions and students' intake}

There is a high demand by high-school graduates in Saudi Arabia for medical education. So the expansion in medical programmes across the country has increased the overall intake of students to around 2500 students. The medical education programme is mainly via undergraduate entry and runs for 6 years, followed by a 1-year internship. KSAUHS has a graduate entry programme that runs for 4 years plus the 1-year internship for holders of a bachelor's degree in applied or medical sciences.

Admission to medicine programmes used to be solely according to highschool grades, in which students with the highest grades were admitted. Later, a written science examination (in English) and interview were introduced as part of the selection process. In 2002, the National Centre for Assessment in Higher Education was established. The Centre is responsible for conducting a national standardized aptitude examination for high-school leavers who wish to apply to the universities for medicine. At present, admission to any medical college in the country is based on high-school grades, the national aptitude test, a summative examination in science and an interview. Some of the colleges are not using the interview because of lack of evidence of it objectivity and reliability.

Medical schools are being challenged to admit more students. In view of the considerable attrition rate among medical students, such an expansion increases the pressure to maintain a high number of quality, competent graduates. Calls have increased among academics to strengthen the student admissions policies and enhance the objectivity of admission interviews.

\section{Accreditation}

Saudi medical schools have 2 professional functions: medical education and health care. Concerning the educational role, until 2005, institutes of higher education, including medical colleges, required no accreditation. In 2005, the Council of Higher Education approved the establishment of the NCAAA, tasked with ensuring the quality of higher education in the country. It is now mandatory for every institute of higher education to be accredited by the NCAAA. The accreditation criteria are comprehensive and include all aspects of an institute, in particular teaching and learning. The accreditation period is limited to 7 years, after which the institute will be revisited for re-accreditation [16]. The process of self-evaluation for all the existing institutes has begun and aims to identify the strengths and weaknesses of colleges and their teaching programmes. The Commission has also started reviewing some medical schools. While this is a step in the right direction, the process itself will need to be evaluated for its impact on the quality of medical education.

Concerning the professional role, the Saudi Commission for Health Specialties is an independent body involved in accreditation of postgraduate programmes, board examinations, professional classification and registration. The Commission runs a national examination-the Saudi Licensing Examination - that national and international graduates doctors are required to take for residency programmes or job placement in Saudi Arabia. The examination consists of 100 multiplechoice questions. Examination statistics are published annually by the Commission, including comparison tables of the scores of graduates from all the colleges. It is believed that such comparisons should be a strong motivation for each medical college to improve the students' scores, which will be reflected in the Commissions statistics. It is considered as an indirect method of quality assurance and a stimulation for improvement and development among institutions.

Again, the effectiveness of the examination as a quality indicator of medical graduates' competencies has not yet been investigated. There have been proposals for a 2-part national licensing examination for all Saudi medical school graduates as well as overseas graduates: a written part for measuring the basic and clinical science and a practical part for evaluating graduates' clinical and interpersonal skills [17]. Certainly such a scheme will face many challenges and assessing stakeholders' views of the issue is essential at this stage. In the meantime, a national survey of senior students' and interns' views of the national licensing examination is being carried out [Zaini R, personal communication].

\section{Challenges}

Many challenges face medical education in Saudi Arabia. The rising global demand for health practitioners in general and physicians in particular is a major challenge worldwide. The mushrooming of medical colleges in the country places tremendous pressure on the MOHE to provide a proper infrastructure and qualified personnel that are well trained in medical education. In addition, the expansion of the new medical colleges, if not carefully planned, might eventually raise questions about quantity versus quality of medical training. 
The pace of reform in Saudi medical education is slow and there are difficulties in its execution. Most of the reforms are directed towards the content of curricula, without defining the essential skills, knowledge, behaviour and standards (outcome-based approach) that graduating physicians need. Sometime the revised curricula have not led to any obvious reforms and this raises concerns that Burton and McDonald [18] express in their paper entitled: "Curriculum or syllabus: which are we reforming?"

In addition, learning medicine in a foreign language (English) has to be addressed. Medical colleges recruit the topmost high-school graduates, yet the attrition rate from medical school is still high. This is multifactorial, but the language of instruction seems to be an important factor [19]. Certainly the current criteria for student selection do not consider students' proficiency of English language.

An additional challenge is to provide the new colleges with adequate numbers of qualified staff. The Gulf Cooperative Council countries Committee of Deans of Medical Colleges agreed that the minimal acceptable faculty-to-student ratio is $1: 7$. However, some of the already established colleges are facing shortages in the number of faculty, with a faculty-to-student ratio far from what these recommendations. The problem is compounded by an unfavourable faculty salary scale as compared with other institutes and private hospitals, a similar situation to Malaysia [20].

Another challenge that faces all Saudi higher education institutes is maintaining and assuring quality. This is the responsibility of the recently established NCAAA, whose effectiveness and efficiency has yet to be established.
Many medical educators call for an independent medical education professional body to govern the health and medical colleges. On the other hand, an objective national graduation licensing examination is a possible means of providing a quality indicator for medical schools.

\section{Conclusion}

Medical education in Saudi Arabia is in a crucial phase that will chance the face of medical education in the country. Systematic planning that considers all potential challenges must be undertaken. The current phase of reform and expansion must be coupled with accreditation and quality assurance procedures in order to ensure that each endeavours are directed towards internationally acknowledged goals and standards.

\section{References}

1. Health statistic book for the year of 2006, Riyadh, Saudi Arabia, Ministry of Health, 2006.

2. Al-Gindan $\mathrm{YM}, \mathrm{Al}$-Sulaiman AA, Al-Faraidy A. Undergraduate curriculum reform in Saudi medical schools. Which direction to go? Saudi Medical Journal, 2000, 21:324-326.

3. Elfaki EA. Undergraduate curriculum reform in Saudi medical schools. Saudi Medical Journal, 2004, 21:324-326.

4. Al-Shehri MY, Al-Ghamdi AS. Is there anything wrong with undergraduate medical education in Saudi Arabia? Saudi Medical Journal, 1999, 20:215-218.

5. Shawky S, Soliman NK. Going beyond the curriculum to promote medical education and practice in Saudi Arabia. Saudi Medical Journal, 2001, 22:477-480.

6. Milaat WA, El-Gamal FM. Factors affecting the use and attitude towards medical resources and educational methods in a Saudi medical school. Annals of Saudi Medicine, 1994, 14(3):209-214.

7. Harden RM et al. BEMEguide no. 1. Best evidence medical education. Dundee, United Kingdom, Association for Medical Education in Europe, 1999.

8. Roff S et al. Development and Validation of the Dundee Ready Education Environment Measurement (DREEM). Medical Teacher, 1997, 19:295-299.

9. Al-Hazimi A et al. Educational environment in traditional and innovative medical schools: a study in four undergraduate medical schools. Education for Health, 2004, 17:192-203.

10. Ahmed AM. Deficiencies of history taking among medical students. Saudi Medical Journal, 2002, 23:991-994.
11. Khalid BA. The current status of medical education in the Gulf Cooperation Council countries. Annals of Saudi Medicine, 2008, 28:83-88.

12. Harden RM. Planning a curriculum. In: Dent J, Harden RM, eds. A practical guide for medical teachers. Edinburgh, Churchill Livingston, Harcourt Publishers, 2001.

13. AlFaris E, Abdulgader A, Alkhenizan A. Towards evidencebased medical education in Saudi medical schools. Annals of Saudi Medicine, 2006, 26:429-432.

14. Frank RA. Medical communication: non-native English speaking patients and native English speaking professionals. English for Specific Purposes, 2000, 19:31-62.

15. Sebai ZA. Why do not we teach medicine in Arabic? In: Proceedings of the VII Saudi Medical Meeting. Dammam, Saudi Arabia, King Faisal University, 1982:74-75 [in Arabic].

16. Handbook 1. Standards and processes for quality assurance and accreditation. Riyadh, Saudi Arabia, National Commission for Assessment and Academic Accreditation, 2005.

17. Bajammal $S$ et al. The need for national medical licensing examination in Saudi Arabia. BMC Medical Education, 2008, 8:53.

18. Burton JL, McDonald S. Curriculum or syllabus: which are we reforming? Medical Teacher, 2001, 23:187-191.

19. Al-Shammri E. [The role of Arabization of higher education in the development of manpower and achievement of Saudization. In: Symposium of Disseminating Arabization and the Development of Translation in the Kingdom]. Riyadh, King Saud University, Translation Centre, 1998:75 [in Arabic].

20. Lim VK. Medical education in Malaysia. Medical Teacher, 2008, 30:119-123. 